\title{
Krempfielins N-P, New Anti-Inflammatory Eunicellins from a Taiwanese Soft Coral Cladiella krempfi
}

\section{Yan-Ning Lee ${ }^{1}$, Chi-Jen Tai ${ }^{1}$, Tsong-Long Hwang ${ }^{2}$ and Jyh-Horng Sheu ${ }^{1,3,4,5, *}$}

1 Department of Marine Biotechnology and Resources, National Sun Yat-sen University, Kaohsiung 80424, Taiwan; E-Mails: jennyyanningl@yahoo.com.tw (Y.-N.L.); jean801023@ hotmail.com (C.-J.T.)

2 Graduate Institute of Natural Products, Chang Gung University, Taoyuan 33302, Taiwan; E-Mail: htl@mail.cgu.edu.tw

3 Division of Marine Biotechnology, Asia-Pacific Ocean Research Center, National Sun Yat-sen University, Kaohsiung 80424, Taiwan

4 Department of Medical Research, China Medical University Hospital, China Medical University, Taichung 40402, Taiwan

5 Graduate Institute of Natural Products, Kaohsiung Medical University, Kaohsiung 80708, Taiwan

* Author to whom correspondence should be addressed; E-Mail: sheu@ mail.nsysu.edu.tw; Tel.: +886-7-5252000 (ext. 5030); Fax: +886-7-5255020.

Received: 11 December 2013; in revised form: 22 January 2014 / Accepted: 7 February 2014 / Published: 21 February 2014

\begin{abstract}
Three new eunicellin-type diterpenoids, krempfielins N-P (1-3), were isolated from a Taiwanese soft coral Cladiella krempfi. The structures of the new metabolites were elucidated by extensive spectroscopic analysis and by comparison with spectroscopic data of related known compounds. Compound $\mathbf{3}$ exhibited activity to inhibit superoxide anion generation. Both $\mathbf{1}$ and $\mathbf{3}$, in particular $\mathbf{1}$, were shown to display significant anti-inflammatory activity by inhibiting the elastase release in FMLP/CB-induced human neutrophils.
\end{abstract}

Keywords: Cladiella krempfi; eunicellin-type diterpenoid; anti-inflammatory agent; elastase 


\section{Introduction}

Soft corals have been known to be rich sources of terpenoid metabolites [1]. For the purpose of discovering bioactive agents from marine organisms, we have previously investigated the chemical constituents and reported a series of bioactive natural products from Taiwanese soft corals [2-5]. In recent studies a series of bioactive eunicellin-based diterpenoids, have been isolated from the soft corals of the genera Cladiella, Klysum and Litophyton sp. [6-14]. The soft coral Cladiella krempfi has been found to produce several types of metabolites including eunicellin-type diterpenoids [15-17] and pregnane-type steroids [18,19]. Our previous chemical investigation of the Formosan soft coral Cladiella krempfi also resulted in the isolation of a series of new eunicellin-type diterpenoids, krempfielins A-M [20-22]. In this paper, we further report the discovery of three new eunicellin-based diterpenoids, krempfielins N-P (1-3) (Chart 1 and Supplementary Figures S1-S9). The ability of these compounds to inhibit the superoxide anion generation and elastase release in FMLP/CB-induced human neutrophils was also evaluated. The results showed that compound $\mathbf{3}$ could inhibit superoxide anion generation while $\mathbf{1}$ and $\mathbf{3}$, especially $\mathbf{1}$, effectively inhibited the generation of the elastase release in FMLP/CB-induced human neutrophils.

Chart 1. Structures of metabolites 1-3.
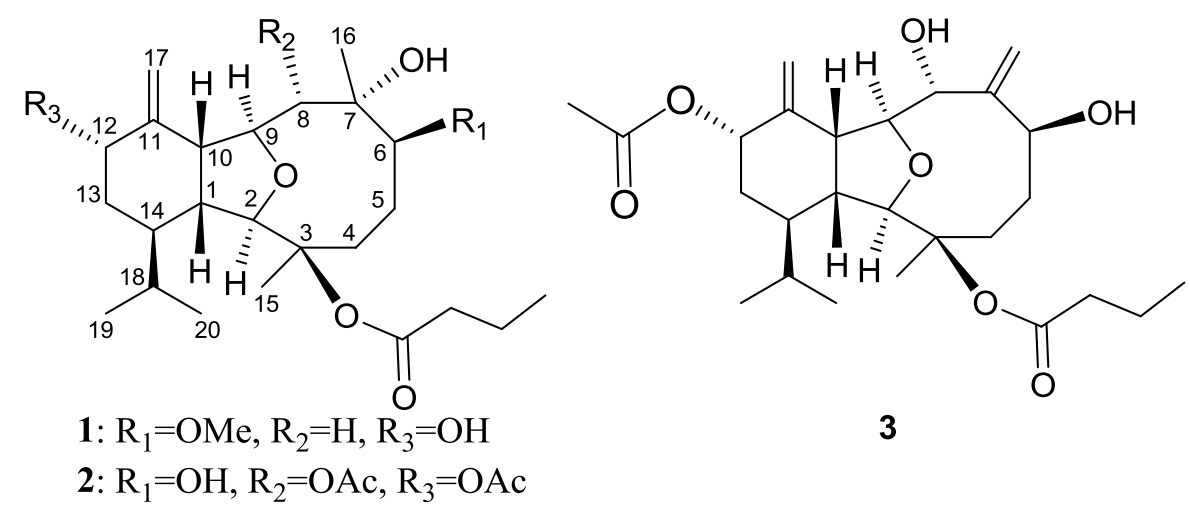

3

\section{Results and Discussion}

The new metabolite krempfielin N (1) showed the molecular ion peak $[\mathrm{M}+\mathrm{Na}]^{+}$at $\mathrm{m} / \mathrm{z} 461.2882$ in the HRESIMS and established a molecular formula of $\mathrm{C}_{25} \mathrm{H}_{42} \mathrm{O}_{6}$, implying five degrees of unsaturation. The IR absorptions bands at $v_{\max } 3445$ and $1733 \mathrm{~cm}^{-1}$ revealed the presence of hydroxy and ester carbonyl functionalities. The ${ }^{13} \mathrm{C}$ NMR spectrum measured in $\mathrm{CDCl}_{3}$ showed signals of 25 carbons (Table 1) which were assigned by the assistance of the DEPT spectrum to six methyls (including one oxgenate methyl $\delta_{\mathrm{C}} 57.0$ ), six $\mathrm{sp}^{3}$ methylenes, one $\mathrm{sp}^{2}$ methylene, eight $\mathrm{sp}^{3}$ methines (including four oxymethines), four quaternary carbons (including one ester carbonyl). The NMR spectroscopic data of 1 (Tables 1 and 2) showed the presence of one 1,1-disubstituted double bond $\left(\delta_{\mathrm{C}} 112.5 \mathrm{CH}_{2}\right.$ and $148.0 \mathrm{C} ; \delta_{\mathrm{H}} 5.03 \mathrm{~s}$, and $\left.4.86 \mathrm{~s}\right)$, one methoxy group $\left(\delta_{\mathrm{H}} 3.34,3 \mathrm{H}\right.$, s) and one $n$-butyryloxy group $\left(\delta_{\mathrm{C}} 172.3 \mathrm{C} ; 37.4 \mathrm{CH}_{2} ; 18.4 \mathrm{CH}_{2}\right.$; and $13.7 \mathrm{CH}_{3} ; \delta_{\mathrm{H}} 2.30 \mathrm{~m}, 2 \mathrm{H} ; 1.67 \mathrm{~m}, 2 \mathrm{H}$; and $0.98 \mathrm{t}, 3 \mathrm{H}, J=7.6 \mathrm{~Hz}$ ). Therefore, taking account of the two degrees of unsaturation from double bonds, it was suggested that $\mathbf{1}$ should be a tricyclic compound from the remaining three degrees of unsaturation. The ${ }^{1} \mathrm{H}-{ }^{1} \mathrm{H}$ COSY and HMBC correlations (Figure 1) were further used for establishing 
the molecular skeleton of $\mathbf{1}$. The COSY experiment assigned three isolated consecutive proton spin systems. Above evidences and the analysis of HMBC spectrum (Figure 1) suggested that $\mathbf{1}$ is an eunicellin-based diterpenoid. Furthermore, the two hydroxy groups attaching at C-7 and C-12 were confirmed by the HMBC correlations from one methyl $\left(\delta_{\mathrm{H}} 1.12 \mathrm{~s}, \mathrm{H}-16\right)$ and one oxymethine $\left(\delta_{\mathrm{H}} 4.12 \mathrm{~m}\right.$, $\mathrm{H}-6)$ to the oxygenated quaternary carbon appearing at $\delta 75.8(\mathrm{C}-7)$, and one methine $\left(\delta_{\mathrm{H}} 2.91 \mathrm{t}, \mathrm{H}-10\right)$ and one proton of $\mathrm{H}_{2}-17\left(\delta_{\mathrm{H}} 5.03 \mathrm{~s}\right)$ to the oxymethine carbon appearing at $\delta 71.0(\mathrm{C}-12)$. Thus, the remaining one $n$-butyryloxy group had to be positioned at C-3, an oxygen-bearing quaternary carbon resonating at $\delta 86.5 \mathrm{ppm}$. On the basis of above analysis, the planar structure of 1 was established. The stereochemistry of $\mathbf{1}$ was finally confirmed by the very similar NOE correlations of both $\mathbf{1}$ and krempfielin L [22].

Table $1 .{ }^{13} \mathrm{C}$ NMR data for compounds $\mathbf{1}-\mathbf{3}$.

\begin{tabular}{|c|c|c|c|}
\hline & $1^{\mathrm{a}}$ & $2^{b}$ & $3^{\mathrm{a}}$ \\
\hline & $\boldsymbol{\delta}_{\mathbf{C}}$ & $\boldsymbol{\delta}_{\mathbf{C}}$ & $\delta_{\mathbf{C}}$ \\
\hline 1 & $44.4, \mathrm{CH}^{\mathrm{c}}$ & $45.1, \mathrm{CH}$ & $43.2, \mathrm{CH}^{\mathrm{c}}$ \\
\hline 2 & $91.0, \mathrm{CH}$ & $91.5, \mathrm{CH}$ & $90.7, \mathrm{CH}$ \\
\hline 3 & $86.5, \mathrm{C}$ & $85.7, \mathrm{C}$ & $84.5, \mathrm{C}$ \\
\hline 4 & $36.0, \mathrm{CH}_{2}$ & 35.7, $\mathrm{CH}_{2}$ & $28.7, \mathrm{CH}_{2}$ \\
\hline 5 & 26.7, $\mathrm{CH}_{2}$ & $28.9, \mathrm{CH}_{2}$ & $35.4, \mathrm{CH}_{2}$ \\
\hline 6 & $89.7, \mathrm{CH}$ & $77.5, \mathrm{CH}$ & $67.0, \mathrm{CH}$ \\
\hline 7 & 75.8, C & 79.4, C & $152.5, \mathrm{C}$ \\
\hline 8 & $45.2, \mathrm{CH}_{2}$ & 79.0, CH & $77.2, \mathrm{CH}$ \\
\hline 9 & $80.0, \mathrm{CH}$ & $79.4, \mathrm{CH}$ & $85.0, \mathrm{CH}$ \\
\hline 10 & $51.4, \mathrm{CH}$ & $50.1, \mathrm{CH}$ & $46.6, \mathrm{CH}$ \\
\hline 11 & 148.0, C & $143.6, \mathrm{C}$ & $141.4, \mathrm{C}$ \\
\hline 12 & $71.0, \mathrm{CH}$ & $73.5, \mathrm{CH}$ & 73.2, $\mathrm{CH}$ \\
\hline 13 & $30.7, \mathrm{CH}_{2}$ & 29.2, $\mathrm{CH}_{2}$ & 29.0, $\mathrm{CH}_{2}$ \\
\hline 14 & $36.6, \mathrm{CH}$ & $37.2, \mathrm{CH}$ & $36.9, \mathrm{CH}$ \\
\hline 15 & $23.2, \mathrm{CH}_{3}$ & $23.1, \mathrm{CH}_{3}$ & $22.1, \mathrm{CH}_{3}$ \\
\hline 16 & 23.6, $\mathrm{CH}_{3}$ & $18.0, \mathrm{CH}_{3}$ & 118.1, $\mathrm{CH}_{2}$ \\
\hline 17 & $112.5, \mathrm{CH}_{2}$ & $115.1, \mathrm{CH}_{2}$ & $119.4, \mathrm{CH}_{2}$ \\
\hline 18 & $28.8, \mathrm{CH}$ & $28.6, \mathrm{CH}$ & 26.9, CH \\
\hline 19 & $16.0, \mathrm{CH}_{3}$ & $15.6, \mathrm{CH}_{3}$ & $15.3, \mathrm{CH}_{3}$ \\
\hline \multirow[t]{2}{*}{20} & $21.8, \mathrm{CH}_{3}$ & 21.7, $\mathrm{CH}_{3}$ & 21.6, $\mathrm{CH}_{3}$ \\
\hline & $172.3, \mathrm{C}$ & 173.0, C & $172.5, \mathrm{C}$ \\
\hline \multirow[t]{3}{*}{ 3-n-butyrate } & $37.4, \mathrm{CH}_{2}$ & $36.7, \mathrm{CH}_{2}$ & $37.4, \mathrm{CH}_{2}$ \\
\hline & $18.4, \mathrm{CH}_{2}$ & $18.5, \mathrm{CH}_{2}$ & 18.5, $\mathrm{CH}_{2}$ \\
\hline & $13.7, \mathrm{CH}_{3}$ & $13.5, \mathrm{CH}_{3}$ & 13.6, $\mathrm{CH}_{3}$ \\
\hline 6-OMe & 57.0, $\mathrm{CH}_{3}$ & & \\
\hline \multirow{2}{*}{ 8-OAc } & & $170.7, \mathrm{C}$ & \\
\hline & & $21.4, \mathrm{CH}_{3}$ & \\
\hline \multirow[t]{2}{*}{$12-\mathrm{OAc}$} & & $170.2, \mathrm{C}$ & 170.1, C \\
\hline & & $21.6, \mathrm{CH}_{3}$ & $21.7, \mathrm{CH}_{3}$ \\
\hline
\end{tabular}

${ }^{\text {a }}{ }^{13} \mathrm{C}$ spectra recorded at $100 \mathrm{MHz}$ in $\mathrm{CDCl}_{3} ;{ }^{\mathrm{b}}{ }^{13} \mathrm{C}$ spectra recorded at $125 \mathrm{MHz}$ in $\mathrm{CDCl}_{3} ;{ }^{\mathrm{c}}$ Deduced from DEPT. 
Table 2. ${ }^{1} \mathrm{H}$ NMR data for compounds $\mathbf{1}-\mathbf{3}$.

\begin{tabular}{|c|c|c|c|}
\hline & $1^{\mathrm{a}}$ & $2^{b}$ & $3^{\mathrm{a}}$ \\
\hline & $\delta_{H}$ & $\delta_{H}$ & $\delta_{H}$ \\
\hline 1 & $2.25 \mathrm{~m}$ & $2.28 \mathrm{dd}(10.0,7.0)$ & $2.26 \mathrm{~m}$ \\
\hline 2 & 3.70 br s & $3.67 \mathrm{br} \mathrm{s}$ & 3.84 br s \\
\hline 3 & & & \\
\hline 4 & $1.86 \mathrm{~m}, 2.64 \mathrm{~m}$ & $1.85 \mathrm{~m}, 2.66 \mathrm{~m}$ & $1.68 \mathrm{~m}, 2.66 \mathrm{~m}$ \\
\hline 5 & $1.33 \mathrm{~m}, 1.65 \mathrm{~m}$ & $1.49 \mathrm{~m}, 1.65 \mathrm{~m}$ & $\begin{array}{l}1.76 \mathrm{~m} \\
2.21 \mathrm{~m}\end{array}$ \\
\hline $\begin{array}{l}6 \\
7\end{array}$ & $4.12 \mathrm{~m}$ & $4.66 \mathrm{~d}(6.5)$ & $4.75 \mathrm{dd}(10.8,4.4)^{\mathrm{d}}$ \\
\hline 8 & $1.82 \mathrm{~m}$ & $5.19 \mathrm{~d}(10.0)$ & $4.20 \mathrm{~s}$ \\
\hline 9 & $4.53 \mathrm{~m}$ & $4.31 \mathrm{dd}(10.0,6.5)$ & $4.43 \mathrm{~d}(10.8)$ \\
\hline 10 & $2.91 \mathrm{t}(6.4)^{\mathrm{c}}$ & $3.38 \mathrm{dd}(7.0,7.0)$ & $2.90 \mathrm{dd}(10.8,8.4)$ \\
\hline 11 & & & \\
\hline 12 & $4.39 \mathrm{~s}$ & $5.43 \mathrm{dd}(4.0,3.0)$ & $5.49 \mathrm{t}(2.8)$ \\
\hline 13 & $1.36 \mathrm{~m}, 1.86 \mathrm{~m}$ & $1.37 \mathrm{~m}, 1.93 \mathrm{~m}$ & $1.30 \mathrm{~m}, 1.98 \mathrm{~m}$ \\
\hline 14 & $1.86 \mathrm{~m}$ & $1.70 \mathrm{~m}$ & $1.71 \mathrm{~m}$ \\
\hline 15 & $1.45 \mathrm{~s}$ & $1.45 \mathrm{~s}$ & $1.65 \mathrm{~s}$ \\
\hline 16 & $1.12 \mathrm{~s}$ & $1.08 \mathrm{~s}$ & $5.23 \mathrm{~s}, 5.55 \mathrm{~s}$ \\
\hline 17 & $4.86 \mathrm{~s}, 5.03 \mathrm{~s}$ & $4.84 \mathrm{~s}, 5.10 \mathrm{~s}$ & $\begin{array}{l}4.96 \mathrm{~d}(1.6) \\
5.27 \mathrm{~d}(1.6)\end{array}$ \\
\hline 18 & $1.81 \mathrm{~m}$ & $1.80 \mathrm{~m}$ & $1.96 \mathrm{~m}$ \\
\hline 19 & $0.82 \mathrm{~d}(7.6)$ & $0.80 \mathrm{~d}(7.0)$ & $0.75 \mathrm{~d}(6.8)$ \\
\hline 20 & $0.99 \mathrm{~d}(7.2)$ & $0.95 \mathrm{~d}(7.0)$ & $0.95 \mathrm{~d}(6.8)$ \\
\hline & $2.30 \mathrm{~m}$ & $2.60 \mathrm{~m}, 2.50 \mathrm{~m}$ & $2.12 \mathrm{~m}$ \\
\hline 3 - $n$-butyrate & $1.67 \mathrm{~m}$ & $1.67 \mathrm{~m}$ & $1.58 \mathrm{~m}$ \\
\hline & $0.98 \mathrm{t}(7.6)$ & $1.00 \mathrm{t}(7.5)$ & $0.92 \mathrm{t}(7.6)$ \\
\hline 6-OMe & $3.34 \mathrm{~s}$ & & \\
\hline 8-OAc & & $2.07 \mathrm{~s}$ & \\
\hline 12-OAc & & $2.08 \mathrm{~s}$ & $2.05 \mathrm{~s}$ \\
\hline
\end{tabular}

${ }^{\text {a } 1} \mathrm{H}$ spectra recorded at $400 \mathrm{MHz}$ in $\mathrm{CDCl}_{3} ;{ }^{\text {b } 1} \mathrm{H}$ spectra recorded at $500 \mathrm{MHz}$ in $\mathrm{CDCl}_{3} ;{ }^{\mathrm{c}} J$ values $(\mathrm{Hz})$ in parentheses.

Figure 1. Selected ${ }^{1} \mathrm{H}-{ }^{1} \mathrm{H} \operatorname{COSY}(-)$ and $\operatorname{HMBC}(\rightarrow)$ correlations of $\mathbf{1 ,} 2$ and $\mathbf{3}$.
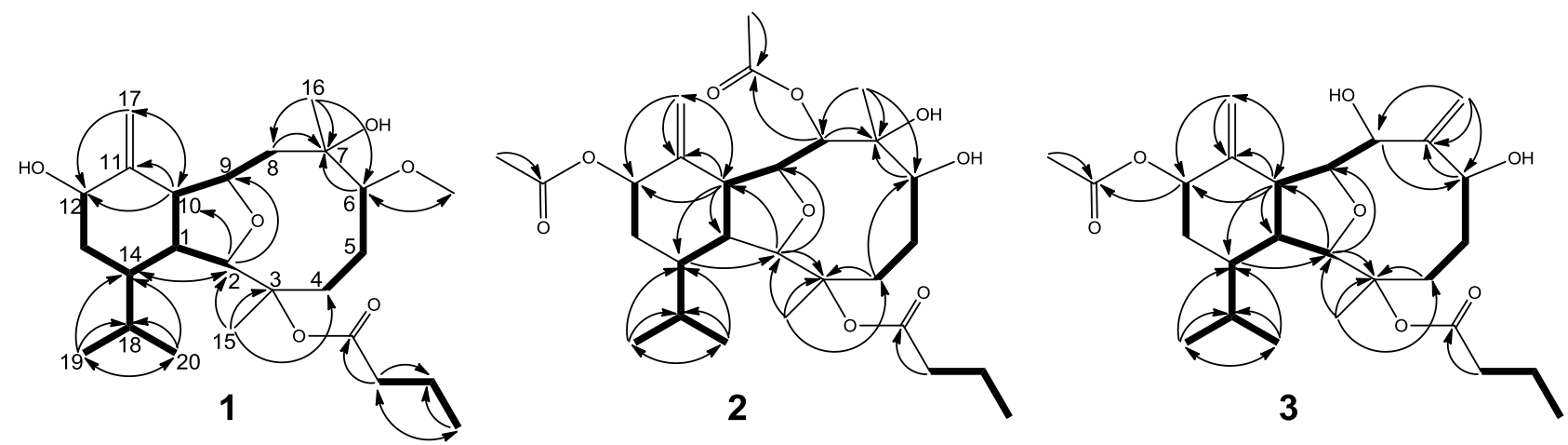
Krempfielin O (2) was shown by HRESIMS to possess the molecular formula $\mathrm{C}_{28} \mathrm{H}_{44} \mathrm{O}_{9}$ $\left(m / z 547.2880[\mathrm{M}+\mathrm{Na}]^{+}\right)$. The NMR spectroscopic data of $\mathbf{2}$ (Tables 1 and 2) showed the presence of two acetoxy groups $\left(\delta_{\mathrm{H}} 2.07\right.$, s and 2.08, s, each $3 \mathrm{H}$; and $\delta_{\mathrm{C}} 170.7, \mathrm{C}$ and 170.2, $\mathrm{C} ; 21.4, \mathrm{CH}_{3}$ and 21.6, $\left.\mathrm{CH}_{3}\right)$, and an $n$-butyryloxy group $\left(\delta_{\mathrm{H}} 2.60 \mathrm{~m}\right.$ and $2.50 \mathrm{~m}$, each $1 \mathrm{H} ; 1.67 \mathrm{~m}, 2 \mathrm{H}$ and $1.00 \mathrm{t}, 3 \mathrm{H}$, $J=7.5 \mathrm{~Hz}$; and $\delta_{\mathrm{C}} 173.0, \mathrm{C} ; 36.7, \mathrm{CH}_{2} ; 18.5, \mathrm{CH}_{2}$ and $\left.13.5, \mathrm{CH}_{3}\right)$. As demonstrated by the HMBC correlation from oxymethine proton $\mathrm{H}-8(\delta 5.19)$ to the ester carbonyl carbon appearing at $\delta_{\mathrm{C}} 170.7$ (Figure 1), one acetoxy group was positioned at C-8. The position of an $n$-butyryloxy group at C-3 was established by NOE interaction between the methylene protons ( $\delta 1.67)$ of $n$-butyryloxy group with H-5 ( $\delta$ 1.49). The remaining one acetoxy group was thus positioned at C-12. The relative configuration of $\mathbf{2}$ was further confirmed by NOE correlations (Figure 2).

Figure 2. Key NOESY correlations for $\mathbf{2}$ and $\mathbf{3}$.
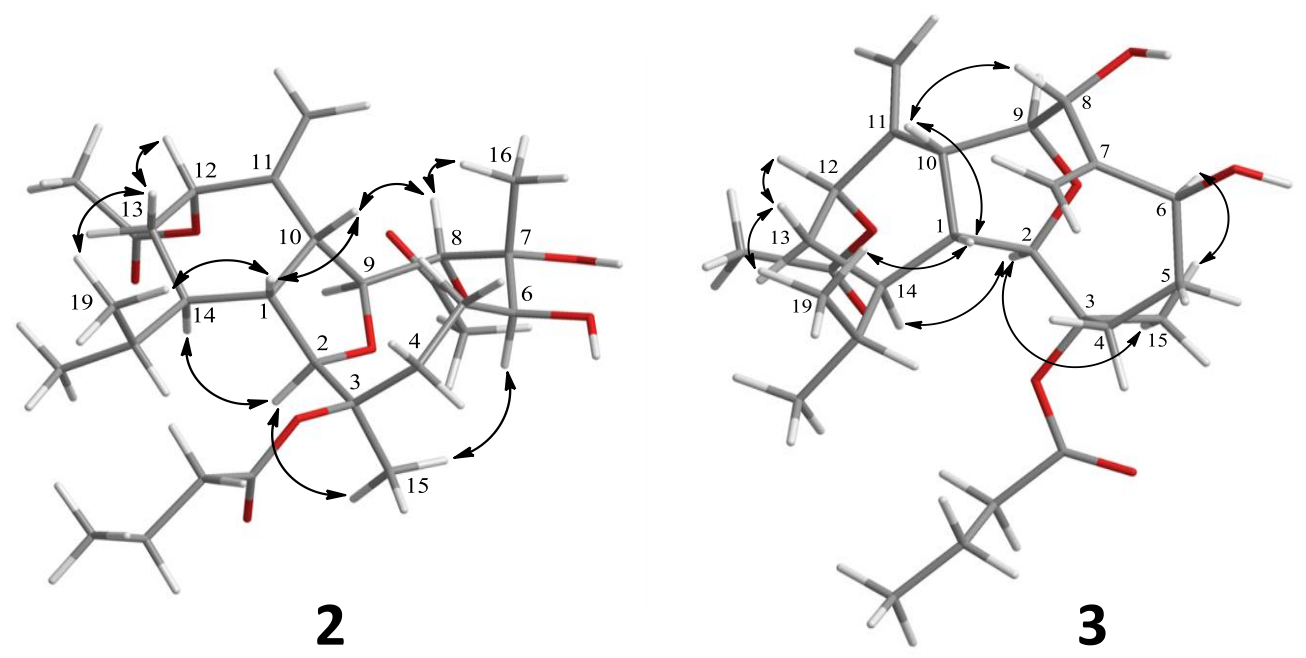

The related metabolite, krempfielin $\mathrm{P}(3)$, had a molecular formula of $\mathrm{C}_{26} \mathrm{H}_{40} \mathrm{O}_{7}$ as indicated by the HRESIMS ( $m / z$ 487.2675, $[\mathrm{M}+\mathrm{Na}]^{+}$) and NMR data (Tables 1 and 2). The ${ }^{13} \mathrm{C}$ NMR spectrum of 3 revealed the appearance of two ester carbonyls $\left(\delta_{\mathrm{C}} 172.5\right.$ and 170.1), which were correlated with one methylene $\left(\delta_{\mathrm{H}} 2.12 \mathrm{~m}, 2 \mathrm{H}\right.$; and $\left.\delta_{\mathrm{C}} 37.4\right)$ of an $n$-butyrate and the methyl $\left(\delta_{\mathrm{H}} 2.05 \mathrm{~s}, 3 \mathrm{H} ; \delta_{\mathrm{C}} 21.7 \mathrm{CH}_{3}\right)$ of an acetate group, respectively. The planar structure of 3 was determined by ${ }^{1} \mathrm{H}-{ }^{1} \mathrm{H}$ COSY and $\mathrm{HMBC}$ correlations (Figure 1). Comparison of the NMR data of $\mathbf{3}$ with those of the compound krempfielin A [20] revealed that the only difference is the replacement of one methyl and one hydroxy group at $\mathrm{C}-7$ in krempfielin $\mathrm{A}$ by the substitution of one olefinic methylene $\left(\delta_{\mathrm{C}} 118.1, \mathrm{CH}_{2} ; \delta_{\mathrm{H}} 5.55\right.$, s and 5.23, s) in 3 . The placement of one $n$-butyryloxy group and one acetoxy group at C-3 and C-12, respectively was established by comparison of the spectroscopic data with those of krempfielin A. The relative configuration of $\mathbf{3}$ was mostly determined to be the same as that of krempfielin A by comparison of the chemical shifts of both compounds and was further confirmed by NOE correlations (Figure 2).

Recently, we discovered several eunicellins showed anti-inflammatory activity by significantly inhibiting superoxide anion generation and elastase release in human neutrophiles induced by $N$-formyl-methionyl-leucyl-phenylalanine/cytochalasin B (FMLP/CB) [22,23]. The same in vitro anti-inflammatory effects of the diterpenoids $\mathbf{1}-\mathbf{3}$ also were tested in this study (Table 3). At a concentration of $10 \mu \mathrm{M}, \mathbf{1}$ and $\mathbf{2}$ could not significantly reduce the generation of superoxide anion, 
however, 3 inhibited $23.32 \% \pm 5.88 \%$ generation of superoxide anion, relative to the control cells stimulated with FMLP/CB only. At the same concentration, all of 1-3 were found to show anti-inflammatory activity by inhibiting the elastase release. Compound $\mathbf{1}$ displayed significant inhibition $(73.86 \% \pm 14.18 \%)$ at this concentration with $\mathrm{IC}_{50}$ of $4.94 \pm 1.68 \mu \mathrm{M}$ in this assay.

Table 3. Effect of pure compounds on elastase release in $N$-formyl-methionyl-leucylphenylalanine/cytochalasin B (FMLP/CB)-induced human neutrophils.

\begin{tabular}{|c|c|c|c|}
\hline \multirow{2}{*}{ Compound } & \multicolumn{3}{|c|}{ Elastase } \\
\hline & Inhibition ( & & $\mathrm{IC}_{50}(\mu \mathrm{M})$ \\
\hline 1 & $73.86 \pm 14.18$ & $* *$ & $4.94 \pm 1.68$ \\
\hline 2 & $13.33 \pm 3.56$ & $*$ & $>10$ \\
\hline 3 & $35.54 \pm 3.17$ & $* * *$ & $>10$ \\
\hline
\end{tabular}

Percentage of inhibition (\%) was measured at $10 \mu \mathrm{M}$; results are presented as mean \pm S.E.M. $(n=3$ or 4$)$; $* p<0.05, * * p<0.01$ and $* * * p<0.001$ compared with the control value.

\section{Experimental Section}

\subsection{General Experimental Procedures}

Melting point was determined using a Fisher-Johns melting point apparatus. Optical rotations were measured on a JASCO P-1020 polarimeter. IR spectra were recorded on a JASCO FT/IR-4100 infrared spectrophotometer. ESIMS were obtained with a Bruker APEX II mass spectrometer. The NMR spectra were recorded either on a Varian UNITY INOVA-500 FT-NMR and a Varian 400MR FT-NMR. Silica gel (Merck, Darmstadt, Germany, 230-400 mesh) was used for column chromatography. Precoated silica gel plates (Merck, Darmstadt, Germany, Kieselgel 60 F-254, $0.2 \mathrm{~mm}$ ) were used for analytical thin layer chromatography (TLC). High performance liquid chromatography was performed on a Hitachi L-7100 HPLC apparatus with an octadecylsilane (ODS) column $(250 \times 21.2 \mathrm{~mm}, 5 \mu \mathrm{m})$.

\subsection{Animal Material}

C. krempfi was collected by hand using scuba off the coast of Penghu islands of Taiwan in June 2008 , at a depth of 5-10 m, and stored in a freezer until extraction. A voucher sample (specimen No. 200806CK) was deposited at the Department of Marine Biotechnology and Resources, National Sun Yat-sen University.

\subsection{Extraction and Separation}

The octocoral (1.1 kg fresh wt) was collected and freeze-dried. The freeze-dried material was minced and extracted exhaustively with $\mathrm{EtOH}(3 \times 10 \mathrm{~L})$. The EtOH extract of the frozen organism was partitioned between $\mathrm{CH}_{2} \mathrm{Cl}_{2}$ and $\mathrm{H}_{2} \mathrm{O}$. The $\mathrm{CH}_{2} \mathrm{Cl}_{2}$-soluble portion (14.4 g) was subjected to column chromatography on silica gel and eluted with EtOAc in $n$-hexane $(0 \%-100 \%$ of EtOAc, stepwise) and then further with $\mathrm{MeOH}$ in EtOAc with increasing polarity to yield 41 fractions. Fraction 31, eluted with $n$-hexane-EtOAc (1:10), was rechromatoraphed over a silica gel open column using $n$-hexane-acetone (3:1) as the mobile phase to afford eight subfractions (A1-A8). Subfraction 
A4 was repeatedly separated by reverse phase $\mathrm{HPLC}\left(\mathrm{CH}_{3} \mathrm{CN}-\mathrm{H}_{2} \mathrm{O}, 0.8: 1\right.$ to $\left.1: 1\right)$ to afford compound 1 (3.2 mg). Subfraction A5 separated by reverse phase HPLC $\left(\mathrm{CH}_{3} \mathrm{CN}-\mathrm{H}_{2} \mathrm{O}, 1: 1\right.$ to 1:1.6) to afford compound $2(1.2 \mathrm{mg})$. Subfraction A6 by reverse phase HPLC $\left(\mathrm{CH}_{3} \mathrm{CN}-\mathrm{H}_{2} \mathrm{O}, 1: 1.5\right)$ to afford compound 3 (3.9 mg).

\subsubsection{Krempfielin N (1)}

Colorless oil; $[\alpha]_{\mathrm{D}}^{25}=+27.3\left(c 0.91, \mathrm{CHCl}_{3}\right.$ ); IR (neat) $v_{\max } 3445,2961,1733,1457,1370,1180$, and $1084 \mathrm{~cm}^{-1} ;{ }^{13} \mathrm{C}$ and ${ }^{1} \mathrm{H}$ NMR data, see Tables 1 and 2; ESIMS $\mathrm{m} / z 461[\mathrm{M}+\mathrm{Na}]^{+}$; HRESIMS $m / z 461.2882[\mathrm{M}+\mathrm{Na}]^{+}$(calcd. for $\mathrm{C}_{25} \mathrm{H}_{42} \mathrm{O}_{6} \mathrm{Na}, 461.2879$ ).

\subsubsection{Krempfielin $\mathrm{O}(2)$}

Colorless oil; $[\alpha]_{\mathrm{D}}^{25}=-56.7\left(c 0.3, \mathrm{CHCl}_{3}\right)$; IR (neat) $v_{\max } 3461,2960,1735,1464,1372,1238$, 1177, 1076, and $1026 \mathrm{~cm}^{-1} ;{ }^{13} \mathrm{C}$ and ${ }^{1} \mathrm{H}$ NMR data, see Tables 1 and 2; ESIMS $\mathrm{m} / z, 547[\mathrm{M}+\mathrm{Na}]^{+}$; HRESIMS $m / z$ 547.2880 [M+ Na $]^{+}$(calcd. for $\mathrm{C}_{28} \mathrm{H}_{44} \mathrm{O}_{9} \mathrm{Na}, 547.2883$ ).

\subsubsection{Krempfielin P (3)}

Colorless oil; $[\alpha]_{\mathrm{D}}^{25}=+13.1$ (c 3.8, $\mathrm{CHCl}_{3}$ ); IR (neat) $v_{\max } 3419,2959,1733,1437,1371,1237$, 1182, and $1072 \mathrm{~cm}^{-1} ;{ }^{13} \mathrm{C}$ and ${ }^{1} \mathrm{H}$ NMR data, see Tables 1 and 2; ESIMS $\mathrm{m} / z$ $487[\mathrm{M}+\mathrm{Na}]^{+}$; HRESIMS $m / z$, 487.2675 [M + Na $]^{+}$(calcd for $\mathrm{C}_{26} \mathrm{H}_{40} \mathrm{O}_{7} \mathrm{Na}, 487.2672$ ).

\subsection{In Vitro Anti-Inflammatory Assay-Superoxide Anion Generation and Elastase Release by}

\section{Human Neutrophils}

Human neutrophils were obtained by means of dextran sedimentation and Ficoll centrifugation. Measurements of superoxide anion generation and elastase release were carried out according to previously described procedures [24,25]. LY294002, a phosphatidylinositol-3-kinase inhibitor, was used as a positive control for inhibition of superoxide anion generation and elastase release with $\mathrm{IC}_{50}$ values of $1.88 \pm 0.45$ and $4.12 \pm 0.92 \mu \mathrm{M}$, respectively. Briefly, superoxide anion production was assayed by monitoring the superoxide dismutase-inhibitable reduction of ferricytochrome c. Elastase release experiments were performed using MeO-Suc-Ala-Ala-Pro-Val-p-nitroanilide as the elastase substrate.

\section{Conclusions}

New eunicellin-based diterpenoids were isolated from the soft coral Cladiella krempfi. Compounds 1 and 3, especially 1, could significantly inhibit the release of elastase in FMLP/CB-induced human neutrophils, and $\mathbf{3}$ inhibited $23 \%$ generation of superoxide anion. Thus, compounds $\mathbf{1}$ and $\mathbf{3}$ are promising anti-inflammatory agents and may warrant further biomedical investigation.

\section{Acknowledgments}

This research was supported by grants from the National Science Council of Taiwan (NSC 102-2113-M-110-001-MY2), Aim for the Top University Program (02C030205) from Ministry of 
Education of Taiwan and National Sun Yat-sen University-Kaohsiung Medical University Joint Project (NSYSUKMU 02C030117), Taiwan, awarded to Jyh-Horng Sheu.

\section{Conflicts of Interest}

The authors declare no conflict of interest.

\section{References}

1. Blunt, J.W.; Copp, B.R.; Keyzers, R.A.; Munro, M.H.; Prinsep, M.R. Marine natural products. Nat. Prod. Rep. 2013, 30, 237-323.

2. Lin, W.-Y.; Lu, Y.; Su, J.-H.; Wen, Z.-H.; Dai, C.-F.; Kuo, Y.-H.; Sheu, J.-H. Bioactive cembranoids from the dongsha atoll soft coral Sarcophyton crassocaule. Mar. Drugs 2011, 9, 994-1006.

3. Chao, C.-H.; Chou, K.-J.; Huang, C.-Y.; Wen, Z.-H.; Hsu, C.-H.; Wu, Y.-C.; Dai, C.-F.; Sheu, J.-H. Bioactive cembranoids from the soft coral Sinularia crassa. Mar. Drugs 2011, 9, 1955-1968.

4. Chao, C.-H.; Chou, K.-J.; Wen, Z.-H.; Wang, G.-H.; Wu, Y.-C.; Dai, C.-F.; Sheu, J.-H. Paraminabeolides A-F, cytotoxic and anti-inflammatory marine withanolides from the soft coral Paraminabea acronocephala. J. Nat. Prod. 2011, 74, 1132-1141.

5. Wen, Z.-H.; Chao, C.-H.; Wu, M.-H.; Sheu, J.-H. A neuroprotective sulfone of marine origin and the in vivo anti-inflammatory activity of an analogue. Eur. J. Med. Chem. 2010, 45, 5998-6004.

6. Chen, Y.-H.; Tai, C.-Y.; Hwang, T.-L.; Weng, C.-F.; Li, J.-J.; Fang, L.-S.; Wang, W.-H.; Wu, Y.-C.; Sung, P.-J. Cladielloides A and B: New eunicellin-type diterpenoids from an Indonesian octocoral Cladiella sp. Mar. Drugs 2010, 8, 2936-2945.

7. Chen, B.-W.; Chang, S.-M.; Huang, C.-Y.; Chao, C.-H.; Su, J.-H.; Wen, Z.-H.; Hsu, C.-H.; Dai, C.-F.; Wu, Y.-C.; Sheu, J.-H. Hirsutalins A-H, eunicellin-based diterpenoids from the soft coral Cladiella hirsuta. J. Nat. Prod. 2010, 73, 1785-1791.

8. Hassan, H.M.; Khanfar, M.A.; Elnagar, A.Y.; Mohammed, R.; Shaala, L.A.; Youssef, D.T.A.; Hifnawy, M.S.; El Sayed, K.A. Pachycladins A-E, prostate cancer invasion and migration inhibitory eunicellin-based diterpenoids from the Red Sea soft coral Cladiella pachyclados. J. Nat. Prod. 2010, 73, 848-853.

9. Chen, B.-W.; Chao, C.-H.; Su, J.-H.; Wen, Z.-H.; Sung, P.-J.; Sheu, J.-H. Anti-inflammatory eunicellin-based diterpenoids from the cultured soft coral Klyxum simplex. Org. Biomol. Chem. 2010, 8, 2363-2366.

10. Chen, Y.-H.; Tai, C.-Y.; Su, Y.-D.; Chang, Y.-C.; Lu, M.-C.; Weng, C.-F.; Su, J.-H.; Hwang, T.-L.; Wu, Y.-C.; Sung, P.-J. Discovery of new eunicellins from an Indonesian octocoral Cladiella sp. Mar. Drugs 2011, 9, 934-943.

11. Hsu, F.-J.; Chen, B.-W.; Wen, Z.-H.; Huang, C.-Y.; Dai, C.-F.; Su, J.-H.; Wu, Y.-C.; Sheu, J.-H. Klymollins A-H, bioactive eunicellin-based diterpenoids from the Formosan soft coral Klyxum molle. J. Nat. Prod. 2011, 74, 2467-2471.

12. Chen, B.-W.; Chao, C.-H.; Su, J.-H.; Tsai, C.-W.; Wang, W.-H.; Wen, Z.-H.; Huang, C.-Y.; ung, P.-J.; Wu, Y.-C.; Sheu, J.-H. Klysimplexins I-T, eunicellin-based diterpenoids from the cultured soft coral Klyxum simplex. Org. Biomol. Chem. 2011, 9, 834-844. 
13. Williams, D.E.; Amlani, A.; Dewi, A.S.; Patrict, B.O.; van Ofwegen, L.; Mui, A.L.-F.; Andersen, R.J. Australin E isolated from the soft coral Cladiella sp. collected in Pohnpei activates the inositol 5-phosphatase SHIP1. Aust. J. Chem. 2010, 63, 895-900.

14. Iwagawa, T.; Kusatsu, T.; Tsuha, K.; Hamada, T.; Okamura, H.; Furukawa, T.; Akiyama, S.; Doe, M.; Morimoto, Y.; Iwase, F.; et al. Cytotoxic eunicellin-type diterpenes from the soft coral Litophyton viscudium. Heterocycles 2011, 83, 2149-2155.

15. Cai, Y.-S.; Yao, L.-G.; Di Pascale, A.; Irace, C.; Mollo, E.; Taglialatela-Scafati, O.; Guo, Y.-W. Polyoxygenated diterpenoids of the eunicellin-type from the Chinese soft coral Cladiella krempfi. Tetrahedron 2013, 69, 2214-2219.

16. Sarma, N.S.; Chavakula, R.; Rao, I.N.; Kadirvelraj, R.; Row, T.N.G.; Saito, I. Crystal and molecular structure of sclerophytin F methyl ether from the soft coral Cladiella krempfi. J. Nat. Prod. 1993, 56, 1977-1980.

17. Lan, W.-J.; Lin, C.-W.; Su, J.-Y.; Zeng, L.-M. Two steroidal glycosides from the soft coral Cladiella krempfi. Chem. J. Chin. Univ. 2003, 24, 2019-2021.

18. Huang, X.-P.; Deng, Z.-W.; Ofwegen, L.V.; Li, J.; Fu, H.-Z.; Zhu, X.-B.; Lin, W.-H. Two new pregnane glycosides from soft coral Cladiella krempfi. J. Asian Nat. Prod. Res. 2006, 8, 287-291.

19. Huang, X.-P.; Deng, Z.-W.; Zhu, X.-B.; Ofwegen, L.V.; Proksch, P.; Lin, W.-H. Krempenes A-D: A series of unprecedented pregnane-type steroids from the marine soft coral Cladiella krempfi. Helv. Chim. Acta 2006, 89, 2020-2026.

20. Tai, C.-J.; Su, J.-H.; Huang, M.-S.; Wen, Z.-H.; Dai, C.-F.; Sheu, J.-H. Bioactive eunicellin-based diterpenoids from the soft coral Cladiella krempfi. Mar. Drugs 2011, 9, 2036-2045.

21. Tai, C.-J.; Su, J.-H.; Huang, C.-Y.; Huang, M.-S.; Wen, Z.-H.; Dai, C.-F.; Sheu, J.-H. Cytotoxic and anti-inflammatory eunicellin-based diterpenoids from the soft coral Cladiella krempfi. Mar. Drugs 2013, 11, 788-799.

22. Lee, Y.-N.; Tai, C.-J.; Hwang, T.-L.; Sheu, J.-H. Krempfielins J-M, new eunicellin-based diterpenoids from the soft coral Cladiella krempfi. Mar. Drugs 2013, 11, 2741-2750.

23. Lin, M.-C.; Chen, B.-W.; Huang, C.-Y.; Dai, C.-F.; Hwang, T.-L.; Sheu, J.-H. Eunicellin-Based diterpenoids from the Formosan soft coral Klyxum molle with inhibitory activity on superoxide generation and elastase release by neutrophils. J. Nat. Prod. 2013, 76, 1661-1667.

24. Yu, H.-P.; Hsieh, P.-W.; Chang, Y.-J.; Chung, P.-J.; Kuo, L.-M.; Hwang, T.-L. 2-(2-Fluorobenzamido) benzoate ethyl ester (EFB-1) inhibits superoxide production by human neutrophils and attenuates hemorrhagic shock-induced organ dysfunction in rats. Free Radic. Biol. Med. 2011, 50, 1737-1748.

25. Hwang, T.-L.; Wang, C.-C.; Kuo, Y.-H.; Huang, H.-C.; Wu, Y.-C.; Kuo, L.-M.; Wu, Y.-H. The hederagenin saponin SMG-1 is a natural FMLP receptor inhibitor that suppresses human neutrophil activation. Biochem. Pharmacol. 2010, 80, 1190-1200.

(C) 2014 by the authors; licensee MDPI, Basel, Switzerland. This article is an open access article distributed under the terms and conditions of the Creative Commons Attribution license (http://creativecommons.org/licenses/by/3.0/). 